\title{
THE WELFARE STATE IN CAPITALIST SOCIETY
}

\section{POLICIES OF RETRENCHMENT AND MAINTENANCE IN EUROPE, NORTH AMERICA, AND AUSTRALIA \\ Ramesh Mishra}

O Mishra identifies three components of the post-war welfare state: full employment, universal social services, and a commitment to social justice. He then considers how different countries approach each of these components. $\$ 50.00$

\section{REPRESENTING ORDER}

\section{CRIME, LAW, AND JUSTICE IN THE NEWS MEDIA}

Richard V. Ericson, Patricia Baranek, and Janet Chan Following the authors' widely acclaimed previous works, Visualizing Deviance and Negotiating Control, this volume analyses news content as an integral part of the crime, law, and justice processes.

Cloth $\$ 50.00$, paper $\$ 19.95$

\section{DUFF PATTULLO OF BRITISH COLUMBIA}

\section{Robin Fisher}

Pattullo was premier of British Columbia from 1933 to 1941. Governing through the tumultuous years of the 1930s, he was the most significant B.C. premier of this century; his Liberal administration offered what was arguably the most vigorous response to the Depression in Canada.

$\$ 40.00$

\section{UNIVERSITY OF TORONTO PRESS}




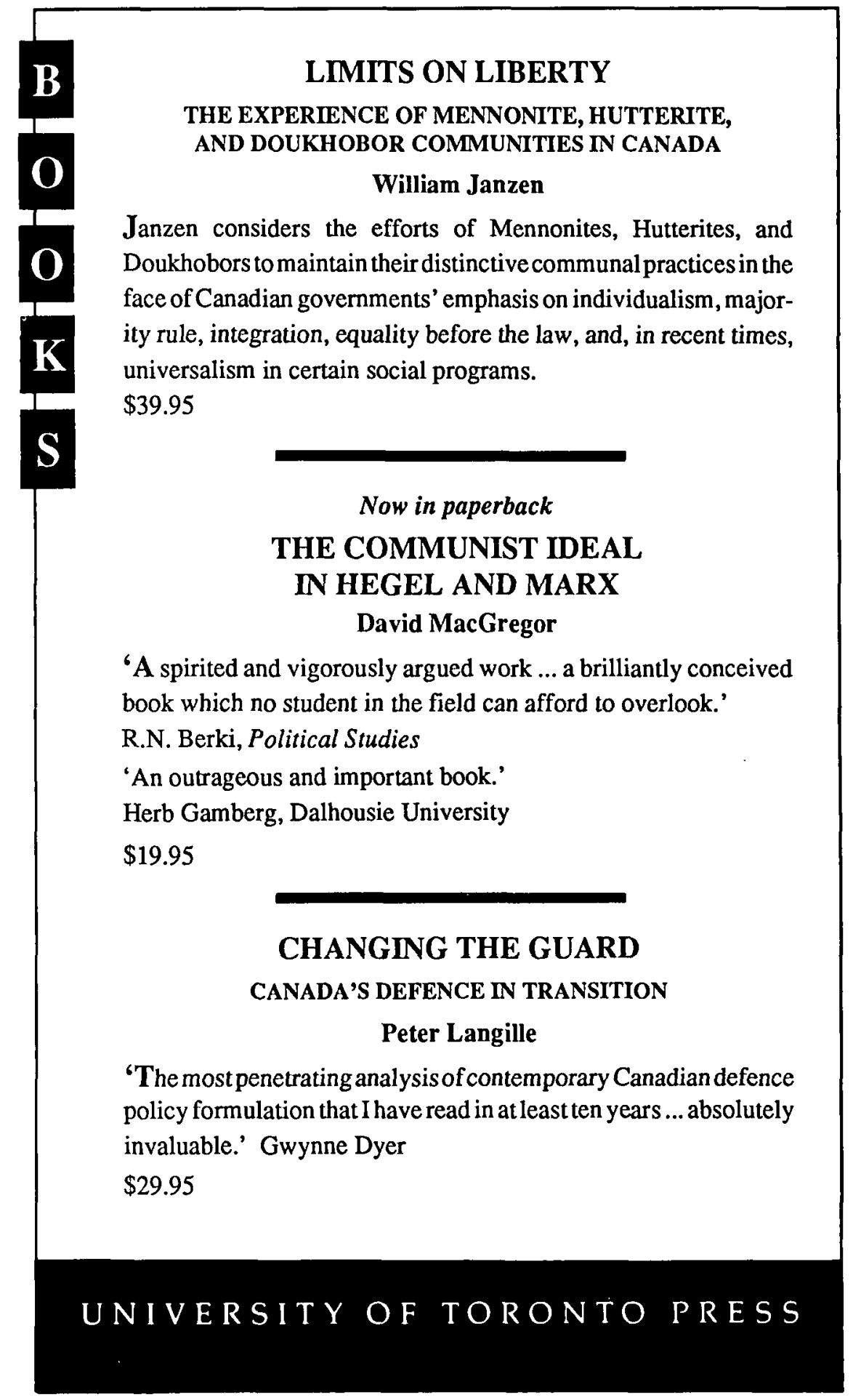




\section{The Supreme Court and Canadian Federalism}

\section{Professor Katherine E. Swinton}

7 his illuminating new work examines the role of the Supreme 1 Court of Canada as constitutional umpire in federal-provincial matters under the direction of Chief Justices Laskin and Dickson. Professor Swinton surveys some 158 decisions by the Court.

- A definitive examination of the Supreme Court's present approach to federalism. Plus an insightful prognosis of the Court's approach to federalism in the future.

- Detailed survey of the Supreme Court's "general regulation of trade" doctrine in giving the federal government greater scope over the regulation of the economy.

- In-depth inquiry into constitutional interpretation. Including the use of economic and historical data as well as human rights theory.

- Revealing insight into the federalist positions of Chief Justices Laskin and Dickson and Justice Beetz - the three key figures on the Supreme Court of Canada who shaped Canadian federalism over the past two decades.

\section{ORDER YOUR COPY TODAY!}

\section{0-DAY RISK-FREE EXAMINATION}

Please send me The Supreme Court and Canadian Federalism for a 30-day risk-free examination.

$\begin{array}{llll}\text { L459-34761 } & \text { August } 1990 & 384 \mathrm{pp} . & \text { hardcover }\end{array} \mathbf{\$ 6 8 . 0 0}$

Name

Address

City Prov

Postal Code Phone No.

T1 Thomson Professional Publishing Canada CARSWELL/RICHARD DE BOO PUBLISHERS

Ordering Address: Corporate Plaza, 2075 Kennedy Road, Scarborough, Ontario M1T 3V4 FAX: (416) 298-5094 (24 bours)

TOLL FREE: 1-800-387-5164 (8:00 a.m. to 8:00 p.m. Eastern Standard Time) IN TORONTO CALL: (416) 609-3800

Price subject to change without notice and subject to the $7 \%$ G.S.T. 


\section{Editorial Policy and Notes to Contributors / Politique éditoriale et avis aux collaborateurs}

The Canadian Journal of Political Science, whose policy is set by the Editorial Board, is committed to the publication of scholarly research in all fields of political science. Manuscripts are assessed on the basis of their contribution to the discipline and by the authors' adherence to the highest scholarly standards. The Editorial Board may judge manuscripts unsuitable if they are too narrow or specialized for an omnibus political science journal.

La Revue canadienne de science politique dont la politique est mise en place par le comité de rédaction s'engage à publier des travaux de recherche académique dans toutes les orientations de la science politique. Les manuscrits sont évalués sur la base de leur contribution à l'avancement des connaissances dans la discipline et selon la conformité des textes aux exigences académiques les plus élévées. Le comité de rédaction peut considérer inadmissibles des manuscrits portant sur des sujets trop spécialisés ou trop étroits.

Authors are requested to forward four copies of their manuscripts together with four copies of an abstract of 100 words. Manuscripts should not be longer than 35 pages (all material included). All material must be double-spaced. Footnotes should be double-spaced and placed in a single listing at the end of the paper. Tables and diagrams must be submitted on separate pages. In preparing a manuscript for consideration by the Editorial Board, authors should follow the JoURNAL's style sheet which the editors can supply. Otherwise, the most recent issue of the Journal can serve as a style guide. Manuscripts will not be returned.

Les auteurs doivent faire parvenir leur manuscrits en quatre exemplaires accompagnés d'un résumé de 100 mots en quatre exemplaires. Les manuscrits ne doivent pas dépasser 35 pages dactylographiées à double interligne (y compris les notes, les références et les tableaux). Les références doivent aussi être présentées à double interligne dans un ordre consécutif à la fin du manuscrit. Les tableaux et les graphiques doivent être soumis sur des pages séparées. Avant de soumettre un manuscrit, les auteurs doivent s'assurer que le protocole de rédaction de la Revue est respecté. Ce protocole peut leur être envoyé sur demande ou ils peuvent s'inspirer à cet égard du dernier numéro de la REvuE. Les manuscrits ne sont pas retournés aux auteurs.

The Editorial Board considers manuscripts on an exclusive basis only; that is, a manuscript submitted for consideration must not have been previously published, nor be under consideration, nor accepted for publication, elsewhere.

Le comité de rédaction considère que les manuscrits lui sont soumis en exclusivité; c'est-à-dire qu'un manuscrit soumis ne doit pas avoir déjà été publié, être soumis ou accepté pour publication dans une autre revue.

Editorial correspondence in English should be directed to Professor Roger Gibbins, Department of Political Science, University of Calgary, Calgary, Alberta T2N IN4.

On doit adresser toute communication en français au sujet de la rédaction au Professeur Stéphane Dion, Département de science politique, Université de Montréal, C. P. 6128, succursale A, Montréal, Québec H3C $3 J 7$. 